consequences of Ukraine's economic development in the contex of globalization]. Recent economic problems, 12 (66), 91-97.

5. Vlasov, V. I. (2001). Global'na prodovol'cha problema[Global food problem ]. Kyiv, 506.

6. Monitoring virobnicho - finansovoj diyal'nosti pidpriemstv i organizatcij APK za 2011 rik (zaklyuchni danni ). [Monitoring of industrial and financial activity of the enterprises and organizations of APC in 2011 (final data) ] (2011). Part II: Agricultural (economic performance). International comparisons. Kyiv.

7. Sych, Z. D. (2005) Novi perspektivi ukrains'kogo ovochivniztva [New Perspectives UkrainianVegetable ] Agronomist, 2, 2-6.

8. Mukoviz, V. S. (2003). Osnovni tendentcii v organizatcii marketing ovochevoi produktcii [Major trends in the marketing of vegetable production]. Ahroinkom, 9-10, 56-61.
9. Yurchenko, A. Yu. Mignarodnij dosvid zastosuvannya sil's'kogospodars'kogo marketing na rinku ovochevoi produktcii [International experience with agricultural marketing market vegetable production]. Available at: http://www.agrosoft.ks.ua/ component/jdownloads/finish/52-/841

10. Tkach, A. V. (2005). Sel'skohozyajstvennaya kooperatciya [Selskohozyaystvennaya kooperatsyya]. Moscow, Russia: Yzdatelskaya torhovaya Corp. "Dashkov i K", 128-132.

11. Zinovchuk, V. V. (2001). Marketingovi kooperativi $\mathrm{v}$ SSHA [Marketing cooperatives in the USA] Rural time, 57 (259), 15 .

12. Hubeni, Y. Y. (2000)/ Transformatciya sil's'kogospodars'kih kooperativiv u Chehii [Transformation of agricultural cooperatives in the Czech Republic]. Economy APC, 2, 87-91.

Рекомендовано до публікачї д-р екон. наук Чірва О. Г. Дата надходження рукопису 25.01.2015

Гуменюк Алла Валеріївна, кандидат економічних наук, доцент, кафедра економіки та підприємництва, ПВНЗ «Свропейський університет» Уманська філія, вул. Шевченка, 15-а, м. Умань, Україна, 20300 E-mail: alika_vostok@mail.ru

УДК 336.71(477)

DOI: 10.15587/2313-8416.2015.37498

\title{
РЕФОРМУВАННЯ ТА СТРАТЕГІЧНИЙ РОЗВИТОК ФІНАНСОВОЇ СИСТЕМИ УКРАЇНИ
}

\section{(C) В. В. Коваленко}

У статті розглянуто основні проблеми розвитку фінансової системи України. Визначено основні напрями реформування фінансового сектору для забезпечення його сталого розвитку, а саме: реформування системи регулювання та нагляуу за фінансовим сектором; реформування самого фінансового сектору через трансформацію монетарної політики та інституційної незалежності Національного банку України

Ключові слова: фінансова система, банківський сектор, реформування, стратегічний розвиток, регулювання, нагляд

The basic problems of development of the financial system of Ukraine are considered in the article. Basic directions of reformation of financial sector are determined for providing its sustainable development, namely: reformation of the system of adjusting and surveillance of financial sector; reformation of financial sector through transformation of monetary policy and institutional independence of the National bank of Ukraine Keywords: financial system, bank sector, reformation, strategic development, adjusting, surveillance

\section{1. Вступ}

Фіна́нсова систе́ма - це сукупність урегульованих фінансово-правовими нормами окремих ланок фінансових відносин і фінансових установ, за допомогою яких держава формує, розподіляє i використовує централізовані і децентралізовані грошові фонди. Фінансова система виникла разом 3 появою держави i нерозривно зв'язана 3 ii функціонуванням. За допомогою фінансової системи держава нагромаджує та використовує кошти для утримання свого апарату, а також спрямовує їх на виконання своїх функцій. Фінансова система охоплюе грошові відносини між державою i підприємствами та організаціями, державою i населенням, між підприємствами і всередині них.

Основними елементами фінансової системи є: загальнодержавні фінанси; місцеві фінанси; фінанси суб'єктів господарювання усіх форм власності; фінанси невиробничої сфери діяльності; фінанси населення; фінансовий ринок; фінансова інфраструктура.

\section{2. Постановка проблеми}

На сьогодні, фінансова система України стикалася 3 труднощами, які пов'язані 3 кризовими явищами фінансової інфраструктури. Фінансова система не виконує належним чином функцію фінансового забезпечення сталого економічного розвитку через недостатню незалежність органів регулювання та нагляду, відсутність інформаційної прозорості, стійкого розвитку, що перешкоджає процесам економічного зростання та інтеграції до світового економічного простору. Тому, ключовими напрямами реформування фінансової системи 
повинно стати: реформування системи регулювання та нагляду за фінансовим сектором; реформування самого фінансового сектору через трансформацію монетарної політики та інституційної незалежності Національного банку України.

\section{3. Літературний огляд}

Проблемам розвитку фінансової системи присвячені наукові праці Абакуменко О. [1], Азаренкової Г. [2], Багратяна Г. [3], Барановського О. [4], Білорус О. [5], Вахненка, Т. [6], Свтуха Л. [7], Сгорова В. [8], Звєрякова М. [9], Козюка В. [10], Міщенка В. [11], Патрікац Л. [12], Школьник О. [13] та багатьох інших. Не зважаючи на достатню увагу науковців до проблеми розвитку фінансової системи України, залишаються не вирішеними питаннями визначення основних напрямів стратегічного іiі розвитку на найближчу перспективу.

\section{4. Цілі та завдання реформування фінансової системи України}

Фінансова система, явище об'єктивне. Це зумовлено тим, що фінансова система виникла 3 появою держави i нерозривно пов'язана 3 iii функціонуванням. В Україні на шляху до ринкового типу фінансової системи накопичилося багато проблем, а саме: відсутність системного підходу до реструктуризації фінансової системи, надто повільний темп реформ, нечітка визначеність 3 конкретним напрямом реформ, відсутня стратегія i тактика, відсутність ефективності функціонування фінансової системи [14]. Фінансова система повинна бути гнучка, динамічна, саморегульована. Держава повинна знайти оптимальний підхід до реструктуризації, керувати розвитком і забезпечувати стабільність всієї системи.

Узагальнений аналіз фінансової системи свідчить про іiі незбалансований характер: як за обсягом ресурсів, так і за роллю у суспільстві провідне місце посідають державні фінанси насамперед бюджет, фінанси суб'єктів господарювання перебувають у стадії трансформації, фінансові інститути перебувають у стадії формування. У нас створені комерційні банки, страхові та клірингові компанії, фондова біржа, державні та недержавні цільові фонди, фінансові посередники, однак їх роль поки що недостатня, що пояснюється слабкою потужністю, яка визначається обсягом фінансових ресурсів [15].

Реформування фінансової системи України необхідно проводити 3 наступних об'єктивних причин.

По-перше. Однин 3 основних елементів «аварійного пакету реформ», - неплатоспроможні банки / фінансові установи, які загрожують макроекономічною дестабілізацією і фіскальними ризиками, тригером набігів вкладників і інвесторів. Реформування фінансового сектору повинно відбуватися задля відновлення макроекономічної i мікроекономічної стабільності з метою запобігання загострення проблеми бідності в короткостроковій перспективі.
По-друге. Здоровий фінансовий сектор є обов'язковим для відновлення довіри (довіра вкладників і інвесторів) і збільшення внутрішніх заощаджень та міжнародних інвестицій, які $\epsilon$ необхідними передумовами для фінансування стійкого зростання (фінансування малого та середнього бізнесу, якість/оновлення технологій i експортне фінансування, інфраструктура).

Основними цілями реформування фінансової системи є:

- стабільний, більш стійкий та менш фрагментарний фінансовий сектор - менше, але краще банківництво, страхування, небанківське кредитування, пенсійні фонди, ринки капіталу тощо;

- більша фінансова глибина (активи, кредити, депозити до ВВП) і фінансова інтеграція (послуги і продукти, якими користуються домогосподарства, малі і середні підприємства та корпорації) 3 метою підтримки економічного зростання i загального процвітання;

- наближення до міжнародних стандартів та практик, включаючи EU/AA, BIS, IOSCO, IAIS, IFRS, IPO, IADI, CPPS тощо;

- більш диверсифіковані ринки, установи, продукти і навички.

Реформування регулювання та нагляду за фінансовим сектором повинно базуватися на запровадженні макропруденційного регулювання та нагляду в НБУ; ефективного функціонування Ради 3 фінансової стабільності при НБУ та департаменту фінансової стабільності в НБУ; створення департаменту мікропруденційного регулювання та нагляду за фінансовим сектором в НБУ; створення на базі Національної комісії з цінних паперів та фондового ринку (НКЦПФР) органу нагляду за бізнес - поведінкою фінансових установ; передача мікропруденційного регулювання та нагляду до НБУ, інших функцій до новоствореного органу на базі НКЦПФР (табл. 1).

Слід відмітити, що фінансова система України не виконує належним чином функцію фінансового забезпечення економічного розвитку через недостатній рівень капіталізації фінансових установ, недостатньої якості та конкурентоспроможності фінансових послуг, недостатній рівень корпоративного управління фінансових установ, системи управління ризиками та незахищеності фінансових установ та споживачів фінансових послуг.

Тому, до реформ високої пріоритетності стратегічного розвитку фінансового сектору України слід віднести:

- оздоровлення фінансового сектору через спрощення процедур реструктуризації/банкрутства підприємств (корпоративних і приватних), створення перехідного банку, пергляд мандатів та управління державними банками, ліквідація кредитних спілок та перетворення їх у корпоративні банки, що дасть змогу ліквідувати неплатоспроможні банки та забезпечити безпеку депозитів - розміщення в «здорових» та стійких банках;

- забезпечення стійкості фінансових установ через посилення вимог до учасників фінансового ринку, 
зокрема капіталу за результатами стрес-тестування. Зазначений напрям призведе до консолідації фінансових ринків із забезпеченням більшої прозорості, ефективності та відкритості фінансових установ; реструктуризація банківського сектору;

- забезпечення інфляції на однозначному рівні через прийняття закону про похідні фінансові інструменти, розвиток інструментів хеджування, регулювання, започаткування пенсійної реформи, зменшення бар'єрів входу/випуску інвестиційних інструментів для пенсійних фондів, страхових компаній, а також поглибити фінансові ринку; запровадження комунікаційної політики НБУ, зокрема щодо інфляційного таргетування.

Таблиця 1

Розподіл сфер відповідальності органів регулювання та нагляду*

\begin{tabular}{|c|c|c|c|}
\hline Сфера відповідальності & $\begin{array}{c}\text { Орган нагляду } \\
\text { за бізнес- } \\
\text { поведінкою } \\
\text { фінансових } \\
\text { установ }\end{array}$ & $\begin{array}{c}\text { Орган } \\
\text { мікропруденційного } \\
\text { регулювання та } \\
\text { нагляду за } \\
\text { фінансовими } \\
\text { сектором НБУ }\end{array}$ & $\begin{array}{l}\text { Фінансова } \\
\text { стабільність } \\
\text { (НБУ }\end{array}$ \\
\hline $\begin{array}{l}\text { Забезпечення стабільності фінансового сектору } \\
\text { (макропруденційний нагляд) }\end{array}$ & & & $\checkmark$ \\
\hline $\begin{array}{l}\text { Мікропруденційне регулювання та нагляд за всіма } \\
\text { фінансовими установами }\end{array}$ & & $\checkmark$ & \\
\hline Управління ризиками (всі фінансові установи) & $\checkmark$ & & $\checkmark$ \\
\hline \multicolumn{4}{|l|}{ Оверсайт платіжних систем } \\
\hline $\begin{array}{l}\text { Регулювання та нагляд випуску та обігу цінних паперів } \\
\text { та похідних фінансових інструментів }\end{array}$ & $\checkmark$ & & \\
\hline $\begin{array}{l}\text { Ліцензування банків, страхових компаній та } \\
\text { недержавних пенсійних фондів, інститутів спільного } \\
\text { інвестування }\end{array}$ & & $\checkmark$ & \\
\hline $\begin{array}{l}\text { Ліцензування інших фінансових установ } \\
\text { (аудиторських компаній, кредитних бюро тощо) }\end{array}$ & $\checkmark$ & & \\
\hline $\begin{array}{l}\text { Розроблення та контроль за дотриманням правил } \\
\text { ведення бізнесу на фінансових ринках (прозорість, } \\
\text { корпоративне управління, конкуренція тощо) }\end{array}$ & $\checkmark$ & & \\
\hline Захист прав споживачів & $\checkmark$ & & $\checkmark$ \\
\hline
\end{tabular}

*Джерело: складено автором за матеріалами: [16, 17]

\section{5. Висновки}

Таким чином, стратегія розвитку фінансового сектору України повинна включати у себе реформи середньо та довгострокової пріоритетності.

По-перше. Підвищення капіталізації фінансових установ через підвищення нормативів капіталізації для банків і небанківських фінансових установ; введення нормативу капіталізації банків для небанківських фінансових установ.

По-друге. Підвищення якості та конкурентоспроможності фінансових послуг через підвищення рівня відповідальності керівників і власників фінансових установ; посилення відповідальності спостережних рад; підвищення якості внутрішнього та зовнішнього аудиту; подальша адаптація нормативно-правової бази України до вимог законодавства ЄС та БКБН; наближення законодавства України до директив СС у галузі фінансових ринків/послуг (у рамках угоди про асоціацію).

По-третє. Розвиток ризик-менеджменту за допомогою швидкого реформування кредитних бюро; запровадження Базель III, Solvency II; вдосконалення обліку та фінансової звітності згідно 3 вимогами Міжнародних стандартів фінансової звітності; удосконалення інфраструктури ринку капіталу та посилення лізингових вимог; перегляд режиму оподаткування інвестування в цінні папери для заохочення капіталовкладень.

По-четверте. Підвищення рівня забезпечення захисту прав кредиторів та споживачів фінансових послуг через реалізацію напрямів стратегії захисту прав споживачів фінансових послуг, зокрема підвищення фінансової грамотності населення, удосконалення законодавства в частині посилення захисту прав кредиторів.

В цілому, стратегічний розвиток фінансової системи повинен забезпечити розбудову в Україні стійкого, прозорого та керованого фінансового сектору, який би сприяв довгостроковому економічному зростанню країни, іiі фінансовій безпеці, був здатним i готовим без загрози національним інтересам інтегруватися у світовий економічний прості.

\section{Література}

1. Абакуменко, О. В. Моделювання точки рівноваги на фінансовому ринку України [Текст] / О. В. Абакуменко // Формування ринкових відносин в Україні. - 2013. № 4. - С. 40-47.

2. Азаренкова, Г. Основні тенденції розвитку фондового ринку в посткризовий період [Текст] / Г. Азаренкова, I. Шкодіна // Вісник Національного банку України.- 2012. - № 2. - С. 3-7. 
3. Багратян, Г. А. Світова криза та Україна: проблеми й нові підходи до фінансового регулювання [Текст] / Г. А. Багратян, І. С. Кравченко //Фінанси України. -2009 . - №4. - С. 33-42.

4. Барановський, О. На шляху до нової фінансової архітектури [Текст] / О. Барановський // Вісник Національного банку України. - 2010. - № 11. - С. 8-15.

5. Білорус, О. Г. Глобальна структурна криза та трансформації фінансової світ-системи [Текст] / О. Г. Білорус // Фінанси України. - 2014. - № 4. - С. 32-46.

6. Вахненко, Т. Взаємодія політики державних запозичень і грошово-кредитної політики у забезпеченні розвитку фінансової системи України [Текст] / Т. Вахненко // Банківська справа. - 2008. - № 2. - С.82-95.

7. Євтух, Л. Б. Функціональні особливості банківських установ у структурі фінансової системи України [Текст] / Л. Б. Євтух //Регіональна економіка. 2008. - № 1. - C. 146-152.

8. Сгоров, В. О. Ресурси фінансової системи і стратегія економічного зростання [Текст] / В. О. Єгоров // Фінанси України. - 2007. - № 9.- С. 133-143.

9. Звєряков, М. I. Формування системи індикаторів фінансової стійкості банківської системи [Текст] / М. І. Звєряков, В. В. Коваленко // Фінанси України. - 2012. - № 4. C. 3-13.

10. Козюк, В. Монетарні аспекти розвитку поглядів на проблему забезпечення глобальної фінансової стабільності [Текст] / В. Козюк // Вісник Національного банку України. - 2007. - № 4. - С. 34-39.

11. Міщенко, В I. Основні напрями забезпечення стабільності фінансового сектору України в контексті глобалізаційних процесів [Текст] / В. І. Міщенко, С. В. Міщенко // Фінанси України. - 2008. - № 5. - С. 56-70.

12. Патрікац, Л. Міцна фінансова система забезпечить Україні гідну позицію на глобальному ринку [Текст] / Л. Патрікац, Р. Підвисоцький // Вісник Національного банку України. - 2012. - № 8. - С. 42-48.

13. Школьник, I. О. Реформування фінансового нагляду під впливом економічної рецесії [Текст] / I. О. Школьник // Фінанси України. - 2010. - № 3. C. $50-61$.

14. Льовочкін, С. Трансформація та розвиток фінансової системи України [Текст] / С. Льовочкін, В. Опарін, В. Федосов // Ринок цінних паперів України. 2003. - № 1-2. - С. 13-14.

15. Кравчук, Н. Фінансова система держави: теоретична концептуалізація та проблеми структурування [Текст] / Н. Кравчук // Світ фінансів. - 2006. - Вип. 3 (8). C. $81-89$.

16. Науменкова, С. В. Нові тенденції в механізмі регулювання фінансового сектору [Текст] / С. В. Науменкова // Вісник Національного банку України. - 2011. № 12. - C. 4-11.

17. Коваленко, В. В. Стратегічні напрями реалізації макропруденційного банківського нагляду та регулювання [Текст] / В. В. Коваленко // Стратегічні пріоритети. 2012. - № 4 (25). - C. 89-97.

\section{References}

1. Abakumenko, O. V. (2013). Design of point of equilibrium at the financial market of Ukraine. Forming of market relations in Ukraine, 4, 40-47.

2. Azarenkova, G., Shkodina, I. (2012). Basic progress of fund market trends are in a post-crisis period. Announcer of the National bank of Ukraine, 2, 3-7.

3. Bagratyan, G. I., Kravchenko, I. S. (2009). World crisis and Ukraine: problems and new going near the financial adjusting. Finances of Ukraine, 4, 33-42.

4. Baranjvskiy, A. (2010). On a way to new financial architecture.Announcer of the National bank of Ukraine, $11,8-15$.

5. Belarus, O. G. (2014). Global structural crisis and transformations of the financial world system. Finances of Ukraine, 4, 32-46.

6. Vahnenko, T. (2008). Co-operation of policy of the state borrowing and monetary policy in providing of development of the financial system of Ukraine.Banking, $2,82-95$.

7. Evtuh, L. B. (2008). Functional features of bank institutions in the structure of the financial system of Ukraine.Regional economy, 1, 146-152.

8. Egorov, I. O. (2007). Resources of the financial system and strategy of economic increase. Finances of Ukraine, 9, 133-143.

9. Zveryakov, M. I., Kovalenko, V. V. (2012). Forming of the system of indicators of financial firmness of the banking system. Finances of Ukraine, 4, 3-13.

10. Kozuk, V. (2007). Monetary aspects of development of looks to the problem of providing of global financial stability. Announcer of the National bank of Ukraine, $4,34-39$.

11. Micshenko, V. I., Micshenko, S. V. (2008). Basic directions of providing of stability financial to the sector of Ukraine in the context of processes. Finances of Ukraine, 5, $56-70$.

12. Patrikac, L., Pidvisoc'kiy, R. (2012). Strong financial system will provide to Ukraine deserving position at the global market. Announcer of the National bank of Ukraine, $8,42-48$.

13. Shkolnik, I. O. (2010). Reformation of financial supervision under act of economic recession. Finances of Ukraine, 3, 50-61.

14. Lovochkin, S., Oparin, V., Fedosov, V. (2003). Transformation and development of the financial system of Ukraine. Market of equities of Ukraine, 1-2, 13-14.

15. Kravchuk, H. (2006). Financial system of the state : theoretical концептуалізація and problems of структурування. World of finances, 3 (8), 81-89.

16. Naumenkova, S. V. (2011). New tendencies in the mechanism of adjusting financial to the sector. Announcer of the National bank of Ukraine, $12,4-11$.

17. Kovalenko, V. V. (2012). Strategic directions of realization of macroprudencail of bank supervision and adjusting. Strategic priorities, 4 (25), 89-97.

Дата надходження рукопису 27.01.2015

Коваленко Вікторія Володимирівна, доктор економічних наук, професор. кафедра банківської справи, Одеський національний економічний університет, вул. Преображенська, 8, м. Одеса, Україна, 65026 E-mail: kovalenko-6868@ mail.ru 